УДК 331.522.4: 004

DOI https://doi.org/10.26661/hst-2019-1-78-09

\title{
THE IMPACT OF DIGITAL TECHNOLOGIES ON THE DEVELOPMENT OF HUMAN AND SOCIAL CAPITAL IN THE CONDITIONS OF THE DIGITALIZED SOCIETY
}

\author{
(C) Микола Кириченко \\ ДВНЗ «Університет менеджменту освіти» \\ E-mail: kmumo@i.ua, ORCID: 0000-0003-1756-9140 \\ ДЗВО «Університет менеджменту освіти» Національної академії педагогічних \\ наук Украӥни, вул.Січових Стрільиів, 52-А (Артема), м. Київ, Украӥна,04053
}

\begin{abstract}
The topic chosen for consideration is extremely important because of great theoretical and practical value and due to the fact that digital world is constantly evolving and influencing the technological capabilities of the modern man, who must constantly increase its resources and capital. Digital technologies are constantly changing the modern market, they have created conditions for the emergence of parallel currencies, erased opportunities between work and leisure, influenced the formation of the digital person and the digital consciousness, the development of digital technologies will affect the digital economy of the future in the future. Digital development is constantly being influenced by the technological and technological changes that affect human and social capital. The level of human and social capital of a modern person must include awareness and advanced technological training to operate in the digital world, to function in well-functioning communications across the country. Analyzing Recent Research and Publications - We draw on recent work in the digital world, namely Mark Goodman's "Crimes of the Future", Max Tegmark's "Life 3.0.The Age of Artificial Intelligence", Stephen Pinker's "Enlightenment of Today. Arguments for Mind, Science, and Progress", Alex Ross's "Industries of the Future," Kevin Kelly's "12 Technologies That Shape Our Future," Eric Brynolfsson and Andrew McAfee's "The Second Age of Machines. Work, progress and prosperity in times of extraordinary technologies" and a number of works of domestic authors - Д.Свириденко, O. Kivlyuk, С.Куцепал, O. Sosnin, O. Punchenko, which explore the relevant topics of this problem. Methods are collections of knowledge about systems of complexity, as the digital age requires systematic thinking in new categories to better understand and refine technological processes. System dynamics can have a greater influence on the development of the technological world and the ideology and outlook of the modern man than the parameters of its individual components. Highlighting previously unsettled parts of the general problem addressed in this article. The basis of the study is the impact of digital technology on the development of human and social capital, because the technology industry is the most dynamic in the modern world, it is able to significantly change our lives in the near future. The purpose of the article is to conceptualize the impact of digital technologies on the development of human and social capital. Research results. It has been proven that the proliferation of digital technologies acts as a megatrend for the digital economy and governance. Identified megatrends of digital economy and digital management that influence the development of human and social capital - valuable printing (brand of 2013); invisible technologies; "Smart cities"; robotics; Artificial Intelligence; internet of things; Big data. The impact of digital technologies on the growth and spread of economic activity and the development of human and social capital is shown. Conditions of creation of new knowledge and technologies as a factor of development of human and social capital are revealed. The place and role of the Internet as a platform for the development of human and social capital is explored. It is substantiated that the impact of digital technologies
\end{abstract}

(C) М. О. Кириченко, 2019 
on the development of human and social capital is a catalyst for the increase of intellectual and digital capabilities of a person capable of living in the digital era.

Keywords: digital technology, human and social capital, artificial intelligence, robotics, digitalized society

\section{Вступ}

Актуальність теми дослідження в тому, що технологічне життя, що сприяє розвитку цифрового суспільства і цифрового управління, $\epsilon$ набором безкінечних оновлень завдяки спільному впливу технологічного прогресу. Розвиток цифрового світу допомагає постійним оновленням, який підтримує інформаційна революція, яку запустив Інтернет, що лише частково стосувалася гіпертексту i людських знань, а, по суті, полягала у тому, що створила новий спосіб взаємодії. Це явище розвинулося у цифрову культуру, яка базується на поширенні (sharing) алгоритмів. Інтернет проник у всі рівні влади, управління, суспільства, громадянського міжнародних діяльності Суспільство не може сьогодні уявити, чим стане Інтернет у майбутньому, так як ми не можемо виміряти колосальних масштабів того, що завдяки технологіям ми створюємо багатший світ, так як комп'ютери допомагають успішно розв'язувати проблеми у різних куточках земного шару. Актуальність теми дослідження в тому, що сучасний світ невпинно розвивається і впливає на спроможність людської цивілізації застосувати розум, інформацію, прогрес, щоб принести користь людству за рахунок ідеалів науки, гуманізму, досягнень за посередництвом інформації. Для цього слід розвивати інформаційнотехнологічну сферу, яка має вплив на формування цифрового світогляду та цифрової ідеології сучасної людини, в основі якого розвиток людського і соціального капіталу [1 ].

\section{1. Літературний огляд}

У своєму дослідженні ми спираємося на розробки зарубіжних авторів, в основі творів яких знаходимо концептуалізацію цифрового суспільства Аппело Юргена «Agile-менеджмент. Лідерство та управління командами» [1]; Аналіз останніх досліджень і публікацій - ми спираємося на останні роботи у світі цифрових технологій, а саме O’ Райлі Тіма «Хто знає, яким буде майбутнє» [28]; Роуза Девіда «Дивовижні технології. Дизайн та Інтернет речей»; Росса Алека «Індустрії майбутнього» [29]; Стайнер Крістофера «Тотальна автоматизація. Як комп'ютерні алгоритми змінюють життя» [6]; Форд Мартіна «Пришестя роботів. Техніка i загроза майбутнього» [39]; Флорида Річарда «Ноmо creatives. Як новий клас завойовує світ» [38]; Шваб Клауса «Четверта промислова революція, Формуючи четверту промислову революцію» [41]; Шарма Ручіра «Передові країни в очікуванні нового

Вплив цифрових технологій на розвиток людського і соціального капіталу в умовах діджиталізованого суспільства 
економічного дива» [40]; Ендрю Макафі, Еріка Бріньолфссона «Машина, платформа, натовп. Як приборкати наше цифрове майбутнє»; Девіда Роуза «Дивовижні технології. Дизайн та інтернет речей»; Пол Мейсона «Посткапіталізм»; Джо Стадвелла «Чому Азії вдалося. Успіхи і невдачі найдинамічнішого регіону світу»; Ручіра Шарма «Передові країни. В очікуванні нового «економічного дива»; Ешлі Венса «Ілон Маск. Tesla, Spacex і шлях у фантастичне майбутнє»; Ліендера Кені «Тім Кук. СЕО, що вивів Apple на новий рівень». Серед вітчизняних вчених ми виокремлюємо роботи В. Г. Воронкової [4]; М. Ю. Максименюк [22]; В. О. Нікітенко [22;24;25]; В. I. Пожуєва [31]; О. П. Пунченка [26]; І. С. Рижової [32]; В. О. Сосніна [36]; А. В. Череп [10], в основі яких викладено розвиток цифрових технологій, за якими майбутнє. В результаті проведеного аналізу літературних джерел, як зарубіжних, так і вітчизняних, ми прийшли до висновку, що з'явився новий науковий напрямок «Філософія цифрового суспільства», що потребує виявлення нового поняттєвокатегоріального апарату, методології дослідження, що акумулюється навколо теорії складності як складової нелінійної методології; теоретичних i практичних основ правових засад інформатизації, цифровізації, роботизації, що розвиваються під впливом глобальних тенденцій; нових понять, категорій, законів, принципів і підходів до захисту інтелектуальної власності у цифровому суспільстві, що розвиваються в нових умовах діджиталізації [27; 28]. Автор спирається на свої доробки, присвячені цифровізації [14;15;16;17]. Методи - сукупності знань про системи складності, так як цифрова ера вимагає системного мислення у нових категоріях, щоб краще зрозуміти й вдосконалювати технологічні процеси. Системна динаміка може потужніше впливати на розвиток технологічного світу та ідеологію і світогляд сучасної людини, ніж параметри окремих іiї компонентів.

На думку авторів, слід зробити акцент на формування нових засад формування людського i соціального капіталу у цифровому суспільстві, що розвиваються під впливом нових глобальних тенденцій розвитку людства інформатизації, цифровізації, роботизації, що розширяють можливості інтелектуалізації, що розвиває різноманітні моделі розвитку науково-технічного та цифрового прогресу, в основі якого - вирішення проблем цифрового суспільства [4]. Незважаючи на наявність цілої низки джерел, все ж таки не розв'язаними i в недостатній мірі проаналізованими залишаються проблеми впливу цифрових технологій на розвиток людського і соціального капіталу у цифровому суспільстві, в основі яких нові тенденції інформатизації, цифровізації, роботизації, що постійно змінюються, тому що цифрове 
суспільство не стоїть на місці, а постійно генерує нове коло проблем, пов'язаних 3 поширенням ідей цифровізації, яка вплинула на розробку TESLA, запуску космічних кораблів i нового фантастичного космічного майбутнього [5]. В результаті проведеного аналізу літературних джерел, як зарубіжних, так i вітчизняних, ми прийшли до висновку, що з'явився новий науковий напрямок філософіï економіки, що потребує виявлення нового поняттєво-категоріального апарату; методології дослідження, що акумулюється навколо синергетичної методології теоретичних i практичних основ філософії цифрового суспільства, які направлені на поглиблення тенденцій інформатизації, цифровізації, роботизації, що розвиваються під впливом глобальних тенденцій; нових понять, категорій, законів, принципів і підходів до філософії цифрового суспільства, що розвивається в нових умовах діджиталізації та дифузії інновацій [7]. На думку авторів, слід зробити акцент на формування нових засад філософії цифрового суспільства, що розвиваються під впливом нових глобальних тенденцій розвитку людства - інформатизації, цифровізації, роботизації, що сприяють розширенню людських можливостей, раніше обмежених як суспільством, так і людиною, що розгортають горизонти технологічному прогресу; під тиском глобальних тенденцій розвивають різноманітні цифрові моделі науково-технічного та цифрового прогресу, в основі якого - вирішення проблем науки, культури, людини, прогресу, гуманізму [30]. Незважаючи на наявність цілої низки джерел, все ж таки не розв'язаними i в недостатній мірі проаналізованими залишаються цифрові тенденції розвитку - інформатизації, цифровізації, роботизації, що постійно змінюються тому, що цифрове життя не стоїть на місці, а постійно генерує нове коло проблем, пов'язаних 3 поширенням ідей цифровізації, в якому відбувається пріоритет цифрової людини і цифрової свідомості, зокрема «12 технологій, що формують наше майбутнє» [18].

\section{3. Мета та задачі дослідження}

Метою даного дослідження $\epsilon$ концептуалізація впливу цифрових технологій на розвиток людського і соціального капіталу.

Для досягнення мети були поставлені такі завдання:

- проаналізувати поширення цифрових технологій як мегатренд цифрової економіки та управління;

- виявити мегатренди цифрової економіки та цифрового менеджменту, які впливають на розвиток людського i соціального капіталу - коштовний друк (бренд 2013); невидимі технології; «розумні міста»; робототехніка; штучний інтелект; інтернет речей; Big data (великі дані);

- показати вплив цифрових технологій на зростання i

Вплив цифрових технологій на розвиток людського і соціального капіталу в умовах діджиталізованого суспільства 
поширення економічної активності та розвиток людського і соціального капіталу;

- розкрити умови створення нових знань і технологій як чинник розвитку людського i соціального капіталу;

- дослідити місце i роль Інтернету як платформи для розвитку людського і соціального капіталу.

Методологія дослідждення трендів цүифрової економіки. Метод «скирти сіна» описує процес, де спочатку треба зосередится на збиранні історій та ідей (скирта сіна) i тільки потім використовувати їх, щоб визначити тренд («голка»), який об’єднує їх. Суть даного методу полягає у збиранні інформації й логічному іiі групуванні. «Голка»- це той сенс, який об'єднує всю зібрану інформацію для створення певного тренду. Головні складові методології дослідженя трендів:

1) збирання - зберегти цікаві ідеї чи історії внаслідок будь-якої взаємодії з людиною чи процесом;

2) найменування - придумати елегантний опис окремих ідей i згрупуваити їх за однією проблемою;

3) доведення (оцінити без упередженості);

4) об'єднання (сполучити у групи);

5) розвиток (визначити спільні теми та описати їх за загальною концепцією).

Цифрова економіка та цифрове управління свідчить, що Кремнієва долина стартувала кілька десятиліть тому, розпочавши зі створення досконалого середовища для застосування бізнесів, пов'язаних 3 інтернетом. Розвиток таких напрямів, як геноміка, роботехніка й кіберзахист сприяли розвитку й удосконаленню технічного прогресу. Створення таких багатих на інновації місць, як Кремнієва долина, вимагає особливостей культури на ринку праці, що можуть суперечити місцевим суспільним нормам, i прагненням місцевих лідерів запровадити більший контроль.

На Кремнієву долину й досі випадає великий відсоток інтернеткомпаній, вкладаються колосальні кошти для iі процвітання, конкуренції і спеціалізації за профілем, зосереджуються найкращі фахівці у галузі комп'ютерних наук, створено цикл самопідсилювання і конкуренції талантів, щоб отримувати інвестиції, що в цілому притягує перспективних вчених, інтелектуалів, підприємців. Нині найважливішу роботу у напрямі комерціалізації геномних досліджень зосереджено навколо університетів, де науковці в лабораторіях народжують i розробляють ідеї.

Що ж до робототехніки, то тут початкове лідерство здебільшого тримають осередки, де накопичено значний довід в електроніці й передових виробничих технологіях. Вони розташовані в таких країнах, як Японія, Південна Корея i Німеччина. Алек Росс у роботі «Індустрії майбутнього» відімчав, що сьогодні «з'являються роботи наступного покоління в Південній 
Кореї, розробляються банківські інструменти у тих частинах Африки, де немає банків, застосовуються лазерні технології для підвищення врожайності в Новій Зеландії, а українські студенти перетворюють мову знаків на розмовну мову» $[29$, с. 9].

Цифрова економіка та цифрове управління зводиться до того, що загальна кількість веб-сторінок, зокрема тих, що генеруються під запит, перевищує 60 трильйонів, а це майже 10000 сторінок на кожного мешканця планети. Такого цифрового мислення не було ніде на планеті у жоден момент іiі історії, Інтернет запустив новий процес становлення i розквіту, проник в усі куточки земної кулі і в усі виді людської життєдіяльності, а сьогодні він $\epsilon$ вершиною цифрового суспільства і цифрового управління. Усі прояви упровадження стратегій розвитку цифрового суспільства та цифрового управління у сучасній Україні спираються на цифрові технології і «технічний прогрес $\epsilon$ потужним двигуном покращення i достатку», - відмічають Ерік Бріньолфссон та Ендрю Макафі у роботі «Друга епоха машин» [3, с. 130]. Контент-менеджмент i контент-маркетинг поширюються, i ця тенденція, без сумніву, пов'язана 3 цифровізацією. Ідея, згідно 3 якою бренди можуть i мусять забезпечувати більшу користь для потенційних клієнтів, змушує бренди інвестувати у створення якісного контенту, перерозподіл маркетингових витрат i революцію у маркетингу i менеджменті, що не має ознак уповільнення.

Упровадження стратегій розвитку цифрового суспільства та цифрового управління у сучасній Україні свідчить, що ці стратегії слід постійно оновлювати, тому що найновіші комп'ютери застарівають. Сьогодні всі урядовці, вчені, експерти, прості люди сприймають еволюцію цифрових оновлень як норму, так як з'явився бренд, що «технологічне життя $\epsilon$ набором безкінечних оновлень і саме життя диктує, що ми не повинні відставати, спричиняючи проблеми завтрашнього дня» [3, с. 19].

1. Поширення цицфрових технологій як мегатренд ичифрової економіки та управління.

Технічній прогрес, складовою якого $\epsilon$ цифровий, $\epsilon$ потужним двигуном достатку, добробуту, процвітання країн, управління економічним розвитком. Батьківщиною інноваційних проектів $€$ Кремнієва долина, побудована на високих технологіях. «Рецепт» успіху «наступної» Кремнісвої долини такий:

1. Побудувати великий, гарний обладнаний усім потрібним технологічний парк.

2. Поєднати в одному місці дослідницькі лабораторії й академічні центри.

3. Створити стимули для залучення науковців, фірм i користувачів.

4. Налагодити взаємні зв'язки всередині індустрії, створивши

Вплив цифрових технологій на розвиток людського і соціального капіталу в умовах діджиталізованого суспільства 
консорціуми і спеціалізованих постачальників.

5. Захистити інтелектуальну власність i забезпечити комерціалізацію технологій.

6. Створити сприятливе бізнессередовище і регулятивні норми». зауважує Алек Росс [29, с.211].

Технології дають життю потенціал для досі небувалого розквіту або для самознищення. Процес підкорення сучасного світу алгоритмами, тобто технологіями, відбувається надзвичайно активно в будь-якій галузі виробництва будь-то бухгалтерська галузь чи відділ обслуговування клієнтів. Алгоритми i комп'ютерні боти завойовують ринки й трансформують суспільство, а між тим робити їм це вдається завдяки певним трендам. Евклідовим алгоритмом, як його часто називають науковці, нині рясніє програмне забезпечення, що використовується у десятках сучасних галузей, включаючи сучасну музику.

Аналіз результатів теоретичних досліджень цифрової економіки i цифрового менеджменту $[4$, с.2021] дозволяє дійти висновку, що завдяки глобальним трендам можна легко маневрувати у майбутньому та усвідомлено контролювати свої наміри i мету, щоб докорінно змінити бізнес, кар'єру та досягти успіху. Головний секрет прогнозування глобальних трендів цифрової економіки i цифрового менеджменту - це здатність навчитися краще розуміти, що відбувається нині [4, с.20-21].
Ми дотримуємося думки, що створення контенту стане новою тенденцією цифрової економіки, яка описує значущість достовірності бренду, що викликає довіру споживачів, проте необхідно сформувати у собі мистецтво визначати тренди. Найвпливовіші тендецнії можуть надати прогнози у короткостроковій перспективі, грунтуючись на дослідждуваному сьогоденні. Для цього слід вивчати результати експериментів, працювати над описом через створення теорій та провести ефективне наукове дослідження, яке вимагає масштабного спостереження.

Слід також навчитися визначати інгредієнти цифрової економіки, вивчати їх сенс, досліджувати й визначити їх призначення i тенденції розвитку, бачити ровиток цифрової економіки з різних сторін i сфер знання, тобто з точки зору міждисциплінарного підходу, а також 3 точки зору методів кількісного і якісного. Тому тренди - це цілком чіткі передбачення, що 3 часом переростають у тенденції, «які повинні бути об'єктивними, тому що, коли ми втрачаємо об'єктивність, це призводить до того, що ми сприймаємо бажане за дійсне»,- відмічає Рогіт Бгаргава [2, с. 27]. Тренди цифрової еконіомки - це більше, ніж повторення загальновідомих фактів, вони мусять уміщати нові проникливі ідеї, щоб описати мінливе сьогодення.

Словосполучення «цифрова ера» вперше вжили близько 15 років тому для визначення 
покоління, яке не знало світу без інтернету. I тому, коли ми не розпізнаємо потенційні наслідки прогресуючих технологій цифрової ери i не адаптуємося до них, то перед нами може постати перспектива «ідеального шторму» тієї катастрофічної ситуації, за якої наслідки різкого зростання соціальної нерівності й безробіття, спричиненого прогресом технологій, наростатимуть майже паралельно i певним чином посилюватимуть і зміцнюватимуть один одного [2, с. 15].

Отже, тренд - це унікальне досліджуване спостереження, що еволюціонує 3 неочевидного i проходить через стадії ідей впливу i розвитку, що розгортають свій вплив на креативну економіку, креативний бізнес, креативне підприємництво, креативний менеджмент. Автори нового покоління креативного суспільства перетворюються на справжніх шукачів слави - вони використовують соціальні мережі, щоб створити власні бренди, привернути увагу i стати значущими.

2.Проаналізуємо деякі тренди цчифрової економіки та цичфрового менеджменту, які впливають на розвиток людського $i$ соијального капіталу.

\section{1Кочтовний друк (бренд} 2013).

Завдяки цифровій культурі ті об'єкти й моменти, 3 якими ми прагнемо взаємодіяти у друкованому або реальному вигляді, стають для нас більш емоційно цінними та особистими. Той факт, що ми рухаємося до безпаперового світу, здається неминучим. Кожний бізнес-лідер відчуває про потребу у «цифровій трансформації» та відмові від старих способів вести бізнес. Банки рекомендують споживачам отримувати виписки електронною поштою. Посадкові талони авіакомпаній більше не треба друкувати. Багато газет і журналів скорочують наклад або взагалі припиняють випускати друковані видання.

У 2017 році цей тренд значно розширився порівняно із сімейними фотографіями та красивими візітками. Коштовний друк тепер є макроідеєєю i трендом, який відображує еволюцію цих галузей від відродження книгарень до масового колекціонування творів, в основі яких була магія друку, яка сьогодні переходлить до безпаперового осягнення та володіння світом (приклад, водійські електронні посвідчення) [19].

\section{2Невидимі технологї.}

Цифрова економіка встановлює зв'язки через цифрові канали i завдяки програмним технологіям докорінно змінює суспільство і світ людини. Наведено 21 технологічну зміну та ще 2 технології переломнх моментів у динаміці та появі на ринку. Кардіостимулятори та кохлеарні імплантанти - це лише початок розвитку даних трендів цифрової економіки. Такі пристрої надсилатимуть дані у центри спостереження, a, можливо, 
автоматично застосовуватимуть лікувальні препарати. «Розумні» тату та інші унікальні чіпи можуть допомогити в ідентифікації особистості та визначенні місця іiі перебування. Цифрові татуювання виконують корисні функції на зразок розблокування автомобіля, введення кодів у мобільні телефони спрямовуванням пальця або спостереження за функціонуванням організму [20].

2.3«Розумні міста» як бренд нової циифрової економіки.

Щороку журнал Fast Company пубілкує список «Найрозумнішиїх міст світу», у якому розглядає комбінацію 362 показників для визначення найпрогресивніших міст світу. Слово «розумний» вже ширкоо вживають у містах, але воно обмежене тіхнічими даними датчиками, системами управління, додатками. Щороку групу таких міст зазвичай очолюють Барселона, Сінгапур, Копенгаген і Гельсінкі. Сюди входять навіть такі показники, як кількість велиспедів, доступних для спільного використання та кількість громадських заходів, враховуються заходи, які роблять людей щасливішими, здоровішими, захищенішими і мобільнішими.

«Розумний Сінгапур» включає прагнення використовувати технології для «осмислення» міста й безпрецедентного доправляння інформації у реальному часі між урядом i громадянами. Міста повинні реагувати на людину, що $є$ людиноцентричним підходом цифрового управління, за якого мешканці можуть давати відгуки про функціонування міста тим, хто ним управляє. Цифрові технології просто розширюватимуть i підтримуватимуть людські потреби. Мірою того, як розумні міста розвиваються, прагнення створювати технологіi, що гармонійно співіснують 3 довкіллям, стає пріоритетнішим. Необхідно ще знайти певний баланс для впровадження цифрових технологій у життя, а також зробити їх настільки невидимими, щоб вони не заважали [13].

2.4 Робототехніка: позитивні $i$ негативні наслідки изього процесу.

Оскільки використання роботів виходить за межі виробництва й потрапляе до наших будинків i офісів, роботи набувають досконаліших інтерфейсів, подібних до людських, а в деяких випадках мають убудовані мікроособистості. Чимраз частіше відбувається використання роботів в усьому - від виробництва, роздрібної торгівлі й догляду за людьми старшого віку до дослідження незвіданих ділянок океану. Однак рядом 3 цим новаційним використанням роботів виникає безліч питань про те, як ми, люди, будемо ставитися до тих роботів, наскільки вони будуть схожі на нас і які етичні питання можуть виникнути через наші стосунки 3 роботами в коротко-і довгостроковому періоді. Таку тенденцію започатковує епоха Відродження роботів i сучасного Ренесансу, коли наша залежність від них веде до нового періоду просвітництва 2.0 у стосунках 3 технологіями, розуміння того, чим 
вони поступатимуться нам, наскільки вони будуть схожі на людину i що це означатиме для організацій і людства загалом [3, c.171].

Позитивні наслідки цього процесу: спрощення постачання та логістики: більше вільного часу; поліпшення результатів лікування; банкомати як перший приклад застосування цієї технології; більший доступ до матеріалів; «решоринг» - заміщення іноземних працівників на роботів.

Негативні наслідки: втрата робочих місць; відповідальність та підзвітність; повсякденні соціальні норми, завершення ери надання послуг із дев'ятої до п'ятої та цілодобового обслуговування; хакерство і кіберзагрози [11, с.127].

2.5 Ресурсозберігаючі будинки [8]. У 2020 році будинки та енергія, викорстана для їхнього живлення та обігріву, генерувала понад $18 \%$ глобальних викидів парникових газів. Найкращі результати у скороченні викидів досягаються шляхом розробки відповідних рішень для обігріву та кондиціонування повітря, нагрівання води, живлення побутових приладів, освітлення й заморожування.

Основним дослідженням житлових будинків є концепція «пасивного дому», обігрів якого здійснюється пасивним методом від сонячного випромінення та тепла, згенерованого мешканцями й побутовими приладами. Він відповідає наступним критеріям мінімальної функціональності:
1) річні вимоги для обігріву та охолодження становлять менше 15 квт/год на м² на рік;

2) невеличкі повітряні проміжки у конструкції будівлі (перевірені випробуванням 3 використанням аеродверей);

3) споживання первинної енергії становить 120 кв год на м² на рік.

Як свідчать дослідження науковців, концепція «пасивного дому» опирається на посилену ізоляцію та гермевтичність у поєднанні 3 теплообдмінною вентиляцією для постачання свіжого повітря 365 днів на рік 3 мінімальними вимогами до енергії нагрівання. За останні роки «зелені будівлі» стали панівною тенденцією у багатьох комерційних структурах, завдяки чому досягається значне скорочення споживання енергії та води [21, c. 177-179].

2.6 Штучний інтелект як глобальний тренд $i$ візія мабутнього. Комбінація штучного інтелекту і досконалих приладів дає змогу базам даних прогнозувати інформацію, виявляти ідеї й доходити висновків самостійно, практично без втручання людини. У 2014 році 36-річний чоловік 3 Даніі, який втратив ліву руку внаслідок нещасного випалку 3 фейерверком, став першим в історії, хто отримав біонічну руку, здатну відчувати текстуру й форму предметів навпомацки. Датчики на кінчиках пальців генерують електричні сигнали, які потім рука перетврює на серію електричних

Вплив цифрових технологій на розвиток людського і соціального капіталу в умовах діджиталізованого суспільства 
сплесків, що імітують мову нервової системи пацієнта.

Таким чином, рука «розмовляє» 3 пацієнтом i він просто дістає надану інформацію. Це сила самостійних баз даних i вона описує значно більше, ніж біонічні вироби. Завдяки того, як новації в удосконаленні алгоритмів i штучного інтелекту уможливлюють докладніший аналіз у реальному часі, ми відкриваємо світ, де бази даних можуть самостійно переходити від уведення даних до розуміння і дії [23].

2.7 Інтернет речей. Завдяки досягненням у галузях інтегральних мікросхем, програмного забезпечення та мікомініатюризації, 3'явилася реальна можливість створення Інтернету речей (IP), чиї пристрої в основному мають поділятися на дві категорії: датчики та мікроконтролери. Мікроконтролери - це крихітні програмовані мікропроцесори, що мають розміри у декілька міліметрів. Це малопотужні, ультрадешеві комп'ютерні мікросхеми, що можуть бути вбудовані у невизначену кількість пристроїв. Ці мікросхеми отримуватимуть дані від розміщених неподалік датчиків - крихітних пристроїв, здатних контролювати все, що можна виміряти та записати, включаючи температуру, потужність, місце розташування, гідравлічний потік, радіаційне випромінювання, атмосферний тиск, прискоренння, обертання, інтенсивність магінтного поля, висоту над рівнем моря, звуки та відео.
Цей глобальний масив датчиків дозволяє нам сприймати, аналізувати та взаємодіяти 3 навколишнім світом, як ніколи раніше, бо людські можливості у цьому сенсі обмежені. Після збирання ці дані будуть не просто зберігатися, а й оброблятися мікроконтролерами IoT, які керують мініатюрними вимикачами, виконавчими механізмами, сервісомеханізмами, турбінами та двигунами, що здатні автономно взаємодіяти 3 навколишнім фізичним світом. Розвиток високошвидкісних бездротових мереж передачі даних дозволить цим датчикам спілкуватися зі світом, використовуючи різні комунікаційні протоколи та технології.

Вони будуть спілкуватися не тільки 3 іншими корстувачами в Інтеренеті, але й безпосередньо один $з$ одним, створюючи величезні обсяги даних машинно-машинного типу (M2M), які будуть зберігатися й оброблятися 3 більшою швидкістю та знижувати побічні витрати завдяки хмарним технологіям та майже необмеженим можливостям зберігання даних. Особливу загрозу становить кібербезпека. Ризики взламу впливають як на компанії, так і на всі зацікавлені сторони, пов'язані 3 передачею даних та мережами. Репрезентований на Всесвітньому економічному форумі огляд промислового інтернету засвідчив: 76\% бізнес-респондентів вірять, що ймовірність таких атак проти їхніх систем інтернет речей (IP) $є$ «дуже 
чи надзвичайно високою». Ще більше непокоїть те, що інтернет речей (IP) є не просто мішенню для кібератак, але й може також використовуватися для їхнього здійснення [11, с. 256].

Результатом стане постійно існуюче «глобально всепоглинаюче, невидиме мережеве обчислювальне середовище, що стане основою могутньої хвилі технологічних змін. Оскільки ці дані матимуть доступ до Інтернету та почнуть оцінюватися даними один 3 одним, вони забезпечать значне покращення логістики, ефективності роботи працівників, операцій 3 постачання, енергоспоживання, обслуговування клієнтів та власної продуктивності [11, с.329-330]. Інтернет речей - це спосіб показати, що більша частина світу стане частиною мережі, так як комп'ютер поглинає все більшу i більшу частину світу.

Перспектива Інтернету речей (IP) звучить привабливо, оскільки мікросхеми та датчики вбудовуються у повсякденні об'єкти, то ми станемо володіти якіснішою інформацією, а наше життя стане комфортним. Інтернет речей (IP) матиме вплив від П'яти до десяти разів більший, ніж звичайний Інтернет. Побічним продуктом Інтернету речей стане жива, дихаюча, глобальна інформаційна мережа, i саме у цьому середовищі технологія проявить себе у такий спосіб, який ми раніше бачили у науковофантастичних фільмах.
(IP) стане чимось на кшталт електрифікації XX1 століття. Для того, щоб речі могли підключитися до Інтернету та почати спілкуватися одна з одною, спершу вони повинні отримати можливість користуватися технологічним еквівалентом мови, спираючись на численні конкуруючі комунікаційні протоколи та технології, що дає змогу постійно впливати на бізнес, мистецтво, засоби масової інформації, культуру споживання.

2.8 Big data (дані) як тренд ичифрової економіки $i$ циифрового управління (сировина i навіть «нафта»), яка, як i інший природний ресурс, має бути захищеною. Результатом виявляється перехід від взаємозв'язку до гіперзв'язку, i, як i все, на що поширюється дія «закону Мура», він відбувається набагато швидше, ніж ми очікуємо. Глобальні обчислення впливають на всі сфери людських зусиль, включаючи транспорт, енергозабезпечення, фінансування, державне управління, сільське господарство, освіту, громадську безпеку, інфраструктуру подорожей та торгівлю. Всі фізичні об'єкти у майбутньому отримають певну IPадресу i, таким чином, стануть частиною інформаційної технології. Речі, які раніше були «німими», матимуть голос, i кожен об'єкт зможе розповісти свою власну історію.

Усі об'єкти будуть зв'язуватися один $з$ одним і матимуть доступ до глобальних обчислювальних

Вплив цифрових технологій на розвиток людського і соціального капіталу в умовах діджиталізованого суспільства 
потужностей та хмарних сховищ, додатково підсилюючи їх завдяки мобільним та соціальним мережам. Ми будемо жити у світі, де все буде інтерактивним та піддаватися програмуванню.

Оновлений Інтернет зробить можливим дистанційне керування будь-яким об'єктом на Землі, де біти 3 цифрового царства зілл'ються 3 атомами фізичного світу. Кожен об'єкт матиме ідентичність та існування в обох світах - i в фізичному, і віртуальному і коли це станеться, різниця між онлайн і офлайн зникне. Самостійні бази даних, переповнення вже не становить тієї проблеми, котрою вона колись була, завдяки потужній автоматизації даних та їхній здатності діяти у режимі реального часу. Проте існує і торгівля даними. Торгівці даними отримують інформацію від інтернетпровайдерів, емітентів кредитних карток, операторів мобільного зв'язку, банків, бюро кредитних історій, аптек, продуктових магазинів, а ще більше - 3 нашої мережевої активності. Всі дані, які ми щоденно віддаємо даром соціальним мережам - кожен «лайк», або «твіт» - зв’язують, геокодують i сортують для перепродажу рекламодавцям i маркетологам. Мета торговців даними - забезпечити те, що називається «поведінковим таргетингом», «передбачуваним таргетингом» про вас і ваше життя.

Подальше агрегування цих даних, нерегульованих i нічим незахищених, подібне до бомби 3 годинниковим механізмом, бо тими масивами інформації можуть скористатися хакери, що безупинно працюють, викрадаючи соціальні дані, які ми без супротиву повідомляємо про себе. У той час як наші технологічні сили збільшуються, у той же час збільшуються i побічні ефекти i потенційні небезпеки та великі ризики, які так само зростають. Хоча бізнес-витрати на зберігання інформації можуть бути зведені майже до нуля, соціальні витрати можуть виявитися дуже великими, тому майбутнє накладає велику відповідальність на наше суспільство i на кожного 3 нас. Лише один-єдиний зламаний обліковий запис електронної пошти y Fecebook, Google чи Apple може дати хакерам доступ до багаторічних архівів листування, розкладів зустрічей, миттєвих повідомлень, фото і відео, телефонних дзвінків, історій покупок на Amazon, банківських i брокерських рахунків і документів y Dropbox чи Google-диску.

Транснаціональні злочинні угрупування несуть повну відповідальність за 85\% зламів, і їхня мета полягає у тому, щоб відфільтрувати якомога більшу кількість даних із найвищою цінністю. Принаймні $\quad 40 \%$ користувачів соціальних мереж зазнавали небезпеку через один із видів шкідливого програмного забезпечення, у понад 20\% були зламані електронні адреса або обліковий запис соцмереж, тобто сторонні особи без нашого дозволу заволоділи нами [11, с.133]. Тільки в США щорічно жертвами 
крадіжки особистих даних стають 500 тисяч дітей $[11$, c.136].

Ми не враховуємо того, що часто, добровільно надаючи інформацію або через виток даних, полегшуємо це завдання для різноманітних зловмисників «кіберсталкерів», «буллерів» або «ексів», як вони себе називають. Дані, алгоритми, методи їхнього аналізу, технології, використання та застосування надають величезні можливості покращити приватне та громадське життя, a також довкілля. Слід скористатися чудовою нагодою i посприяти розвитку та застосувати цифрові рішення, водночас забезпечивши повагу до прав людини й цінностей, що підтримують відкрите, плюралістичне та толерантне цифрове суспільство.

\section{2. Вплив циифрових}

технологій на зростання $i$

поширення економічної

активності та розвиток

людського і соиіального

капіталу

Станом на сьогодні цифрові технології $\epsilon$ одним 3 найпотужніших чинників зростання та поширення економічної активності у глобальній економці та впливу на розвиток людського i соціального

капіталу. Інформаційний шар, який оточує й організовує сучасний світ, а також керує ним та всіма його частинами, тяжіє до інтернету, тобто до мереж комп'ютерів і людей. Час, відстань і вартість у цьому інформаційному світі скорочуються. Чимало витрат, пов'язаних із віддаленістю ринків і головних офісів, зменшилися 3 появою цієї нової технології і вони насправді стрімко зменшуються.

Великого впливу, вочевидь, варто очікувати на міжнародних ринках у глобальних ланцюгах постачання й доступу до інформації та послуг на віддаленні від цих ланцюгів. Нове зростання цифрових технологій зумовлене застосуванням науки й технологій у виробництві, логістиці та комунікаціях, адміністративними та інноваційними комунікаціями, змінами управління та способах взаємодії політики й уряду, 3 економікою - словом, усіма аспектами сучасного життя, відмічає Майкл Спенс у роботі «Нова конвергенція. Майбутнє економічного зростання в багатошаровому світі [27, с. 17].

Інновації, які іноді називають технічним прогресом, поступово збільшують виробничий потенціал економіки та впливають на розвиток людського і соціального капіталу, що потребує інвестицій в науку, освіту, людину. За однакових затрат капіталу робочої сили та енергії завдяки інформаційно-цифровим

технологіям можна отримувати більше продуктів. Деякі технології заощаджують на праці: ручна обробка інформації зникла 3 появою мережевих комп'ютерів i сучасних інформаційних технологій. Інші технології заощаджують здебільшого на капіталі, вдалим прикладом $\epsilon$ стільниковий зв'язок. Для встановлення дієвої мобільної

Вплив цифрових технологій на розвиток людського і соціального капіталу в умовах діджиталізованого суспільства 
мережі треба значно менше капіталу, ніж для стаціонарної [13].

Цифрові технології справили надзвичайний вплив на усунення інформаційного та комунікаційнотехнологічного розриву між розвинутими країнами та країнами, що розвиваються. Інновації у цифрових технологіях - це щось більше, ніж економічні стимули чи тимчасові ринкові переваги. Розвиток науки, техніки, соціальних наук передує економічному зростанню й уможливлює його. Створенню розширеної бази наукового знання про цифрові технології зумовили економічні стимули [4].

Освіта на всіх рівнях, інвестиції у фундаментальні науки, інженерію та біомедичну сферу, доступ до фінансових та безліч інших систем забезпечення призвели до збігу економічних і соціальних інтересів 3 головними людськими мотиваціями. Освіта стає доступнішою і покращує людський i соціальний капітал, який, у свою чергу, формує навички, компетентності, інформаційного Інформаційні можливості управління. відчиняють двері до «суспільства знань» i як побічний наслідок, прискорюється передача знань, збільшуючи інвестиції в людський та соціальний капітал. Адже економічний розвиток залежить від знань, технологій та інновацій, які ми колективно створюємо, а потім застосовуємо для творення інноваційного прогресу, що став рушійною силою тривалого зростання розвинутих країн [9].
3.1 Умови створення нових знань $i$ технологій як чинник розвитку людського $і$ соцуіального капіталу

Створення нових знань i технологій дорого коштує суспільству й потребує чималої кількості людських ресурсів. Знання $є$ абсолютним суспільним благом, що сприяє економічному зростанню, інноваційному прогресу, веде до швидкого зростання виробничого потенціалу економік, що розвиваються, схоже, інновація та знання здійснюють квантовий стрибок, так як прискорюється поширення продукту - знань. Тому зростання зумовлене розширенням відкритості економіки під впливом цифрових технологій і необхідною умовою для наздогінного зростання. Цифрові інформаційні технології дозволяють різке скорочення щоденних витрат (економісти їх називають транзакційними). Економічний ефект мережевих комп'ютерів виник передусім через різке зниження транзакцій них витрат. Це постійні побутові витрати, необхідні для функціонування економіки.

Вплив цифрових технологій на розвиток людського і соціального капіталу - це здебільшого результат інновацій і технічного прогресу або придбання, передачі й використання технологій та знань у новому середовищі. Технології та знання, навички й ноу-хау, які існують переважно у розвинутих країнах, сприяють економічному 
розвитку та процвітанню розвинутих країн [20; 33].

Інновація - це нове знання, що додається до доданої вартові за рахунок творення нових продуктів, створення нових методів виробництва та зниженням витрат. Вона не з'являється 3 нічого, іiі слід створити, зробити технологічний прогрес складової динамічної моделі й пояснити технологічні основи інноваційно-інформаційної економіки, що сприяє розвитку людського та соціального капіталу.

\section{2 Місце $і$ роль Інтернету} як платформи для розвитку людського і сочуіального капіталу

Стрімко розвиваючись, Інтернет став платформою для цілого ярду наукомістких послуг, які не потребують безпосереднього доступу. Виявляється, список видів діяльності, які відповідають такому опису, неймовірно довгий i неосяжний: електронні банківські послуги, електронні виплати, електронне інвестування, електронний уряд, електронне навчання, електронні дослідження, електронні закупівлі, електронна комерція, електронний бізнес, електронне громадянство, електронна політика, електронні публікації, електронні новини, електронна політика, електронне коментування - i це незначна частина списку цифрової діяльності. Усі згадані сервіси розвиваються через кардинальне зниження витрат на пошук інформації, взаємодію та операції ширше кажучи, через зниження транзакційних витрат.
Як результат - скорочення операційних втрат на інформаційну скеровану діяльність, яка не потребує фізичної близькості, підвищення рівня обізнаності, доступу до інформації, влади споживачів та ефективності рішень. Потужний інформаційний інструмент цифрових технологій може підвищити ефективність будь-якої діяльності, у тому числі й відмивання грошей, тероризму, стеження, координування, злочинних дій та крадіжок особистих даних. Приватна інформація опиняється під загрозою не тільки через імовірність «зламу», але, шо, набагато важливіше, тому, що витрати на збір інформації тепер значно нижчі, ніж раніше.

Перевагою глобальних ланцюгів інформаційних технологій $\epsilon$ використання дешевих ресурсів по всьому світу. Людський потенціал розкиданий по всьому світу i перетворюється на цінний талант шляхом поєднання його 3 освітою, навчанням i продуктивною зайнятістю. Але значна частина цього людського потенціалу недоступна, тому що у світовій економіці товари та капітал мобільні. Щоб отримати користь від таланту, робочі місця повинні йти до людей, або люди мають іти до робочих місць праці, тобто людей. Існує важливий набір наукомістких послуг, які можуть надати тільки люди. Набагато важливішим $є$ процес переходу робочих місць до людей, що зараз і відбувається [12].

Вплив цифрових технологій на розвиток людського і соціального капіталу в умовах діджиталізованого суспільства 
Коли інформаційна технологія усуває потребує фізичної близькості, ринки цих послуг стають глобальний. Роботи рухаються до людей, де б ті не перебували. На ринку праці з'явилися людські ресурси, які раніше були недоступними через віддаленість, сьогодні географічні кордони руйнуються. Інсорсинг та аутсорсинг застосовують у дедалі більшому масиві секторів послуг: в управлінні IT-системами, розвитку програмного забезпечення, бізнеспроцесах, обслуговуванні та підтримці клієнтів.

Перший вагомий вплив інформаційної технології позлягав у технічних змінах - автоматизації та заощадженні робочої сили;

другий - точність, можливість координувати діяльність на значній відстані;

третій - повертає в центр уваги людей, пошук та використання висококваліфікованих людських ресурсів у всьому світі для працемісткої діяльності.

Використання людського i соціального капіталу - це зиск, від якого виграють всі - i уряд, i суспільство, і люди. Сьогодні з'явилася нова тенденція глобальний доступ до людського капіталу i на неї вплинули інформаційно-комп'ютерні та комунікаційні технології, Інтернет, глобальна економіка, ринок праці.

\section{4. Висновки}

Таким чином, можемо відмітити, що у сучасному світі все $\epsilon$ взаємопов'язаним і кожна людина уразлива. Проте ще не все втрачено i ми можемо багато чого зробити, щоб змінити ситуацію. Виклики, що постають перед нами, постійно зростають у великому обсязі, але це стосується не тільки зламаних банківських рахунків або викрадених особистих фотографій. Мова йде не лише про захист i збереження контролю над безліччю пристроїв, якими ми користуємося у повсякденні.

Йдеться про візію і захист нашого технологічного майбутнього, усвідомлення того, що нас чекає далі. Завтрашні взлами впливатимуть на наші автомобілі, GPS-системи, медичні пристрої, що імплантуються, телевізори, ліфти, інтелектуальні вимірювальні прилади, конвейерні лінії та роботів-партнерів.

Сьогодні нам бракує будь-яких життєздатних моделей для справді надійного i безпечного життя. Найкращий спосіб прогнозувати майбутнє - винайти його.

Вже сьогодні ми маємо всі симптоми та індикатори загроз, так як нам доведеться мати справу 3 новою біозброєю, зламаною ДНК та крадіжками генетичної та біометричної інформації. Ми живемо в експоненційні часи, коли інформація подвоюється кожні два роки, коли ми $\epsilon$ технологічно незахищеними, так як всіма критичними системами та інфраструктурами керують комп'ютери. I справа не тільки в IT-проблемах, які пронизують все житття сучасної людини, яка також стикається із соціальними, особистими, фінансовими проблемами, проблемами охорони здоров'я, виробництва і суспільної 
безпеки, транспорту та енергетики, конфіденційності і прав людини.

Завдяки глобальній мобілізації суспільства, як вважає Марк Гудмен, i поверненню повного контролю над нашими пристроями та технологіями, ми зможемо використовувати інструменти виключно на благо людини, i засоби зміни світу - у руках кожного 3 нас, в результаті чого зможемо витримати випробування прогресом i досягти процвітання завдяки розвитку трендів цифрової економіки, цифрового суспільства, цифрового менеджменту [4].

Тренди цифрового суспільства виокремлюються із мінливого сьогодення, проте вже сьогодні можна навести приклади недалекого технологічного майбутнього: Данія завдяки виробництву енергії вітру стане наступною наддержавою світу до 2050 року, або оптимістичних технологічних прогнозів щодо того, як автомобілі із самостійним керуванням дадуть змогу подорожувати у вірутальній реальності під час щоденних поїздок на роботу.

Щоб краще спостерігати за реальністю, слід вже сьогодні готуватися до майбутнього, i навпаки, щоб готуватися до майбутнього слід спостерігати над реальністю, культивувати інновації та інноваційні технології.
Визначати тренди цифрового суспільства (економіки, менеджменту, маркетингу) - це мати широке системне мислення, бачити зв'язок між галузями, ідеями та поведінкою, використовувати теорію складності та гнучкий (адаптований) Agile-менеджмент.

\section{5. Практичні рекомендації}

1. Необхідно у подальшому розвивати цифрові технології та цифрову економіку, які б сприяли технологічному прориву i підвищенню місця і ролі людини у цифровому суспільстві; популяризувати перехід до мережевої, модульної, нелінійної командної роботи. Ми перебуваємо в моменті можливості контрольованого відходу від вільного ринку, від вуглеводневого палива, від примусової праці. Можливо, й поступово держава втратить свою могутність, а іiі функції перейме суспільство.

2. Потрібно аналізувати найкращі традиції цифрового суспільства, представленого високо індустріальними країнами, а також розширяти наукові знання філософії цифрового суспільства як нового наукового напрямку та постійно екстраполювати i упроваджувати у наше життя кращі традиції цифрових технологій, вПливаючи на розвиток людського і соціального капіталу.

\section{REFERENCES}

1. Bryjolfsson, Eric and McAfee, Andrew. (2014). The Second Machine Age: Work, Progress, and Prosperity in a Time of Brilliant Technologies. W.W.Norton Company, 236.

2. Christopher, S. (2018). Total automation. How computer algorithms change life. Kyiv: Our format, 280.

Вплив цифрових технологій на розвиток людського і соціального капіталу в умовах діджиталізованого суспільства 
3. Everett M. Rogers (2009). Diffusion of innovations. Lane. with the English. Basil: Stark Look. House "KyivMohyla Academy", 591.

4. Chang, H.-J. (2018). 23 things they don't tell you about capitalism. Kyiv: Nash format, 296.

5. Cherep A.V., Cherep O.H., Krylov D.V. and Voronkova V. H. (2019). Methodological approach to the redistribution of investment projects within a company According to formal criteria // Financial and credit activity-problems of theory and practice. Volume 28, Issue 1, 256-263.

6. Goodman, Marc (2019). Future crimes. Lane. with the English. I. Mazarčuk, j. Mašiko-Kharkov: Publishing: Morning: Fabula. 592.

7. James, P., Womack, D., Jones, T.and Rus, D. (2017). The machine that changed the world." History of line production - dark weapons "Toyota" in automotive wars. Library Lin Institute. Kyiv: Pavlum, Lean Snicit Ukraine, 388.

8. Kahney Leander (2019). Tim Cook: The Genius Who Took Apple to the Next Level. NY: Penguin. 296.

9. Kevin, Kelly (2017). The Inevitable. Understanding the 12 Techological Forces That Will Shape Our Furure. NY Penguin Books, 304.

10. N. Katherine, Hayles (1999). How We Became Posthuman. Virtual Bodies in Cybernetics, Literature, and Informatics. Chicago London The University of Chicago Press, 426.

11. Maxton, Graeme and Randers, Jorden (2016). Reinventing Prosperity. Managing Economic Growth to Reduce Unemployment, Inequality, and Climate Change. A Repport to the Club of Rome. Vancouver: Grestone Books, 320.

12. Meadowz, Donella, Randers, Jorders and Meadows, Dennis. (2006). Limits to Growth The 30-Year Update. London·Sterling VA. 464.

13. Maksimeniûk M. Yu., Nikitenko V. O. (2016). Formation of the paradigm of information-communicative society as a kind of complex social systems, and the interaction // Humanitarian Bulletin of Zaporizhzhya State Engineering Academy, 66, 266-278.

14. Maxton, Graeme and Randers, Jorden (2016). Reinventing Prosperity. Managing Economic Growth to Reduce Unemployment, Inequality, and Climate Change. A Repport to the Club of Rome. Vancouver: Grestone Books, 320.

15. Nikitenko, V. O. (2013). Geokulturni values in today's world development: a sociophilosophical dimension. Humanities Bulletin of Zaporizhzhe State Engineering Academy, 54, 266-280.

16. Nikitenko V. O. Human values as geocìnnostì global scale: the anthropological dimension. Humanitarian Bulletin of Zaporizhzhya State Engineering Academy, 55, 131-138.

17. Punchenko, O. P. and Voronkova, V. H. and Andriukaitiene, R. (2018). Sociodynamics of the globalizing world in its civilization dimension. Humanities Bulletin of Zaporizhzhe State Engineering Academy, 74, 48-60.

Doi: https://doi.org/10.30839/2072-7941.2018.149652

18. O' Reilly, Tim (2018) Who knows what will be the future. Lane. with the english Yulia Kuzmenko. K.: Our format, 448.

19. Alec Ross (2017). The industry of the future / lane. with the English. Natalia Košmanenko. PS: Our format. 320.

20. Steven, Pinker (2018). Enlightenment Now. The Case for Reason, Science, Humanism, and Progress. New York: Viking. 560

21.Pozhuev, V. (2010). Understanding the place and role of information in modern society. Humanities Bulletin of Zaporizhzhe State Engineering Academy, 42, 4-13

22. Ryzhova, I. (2011). Culture is the most fundamental way of human existence. Humanities Bulletin of Zaporizhzhe State Engineering Academy, 46, 126-134.

23. Rogers, E. M. (2009). Diffusion of innovations. Kyiv: Publishing House: KyivMohylian Academy, 591.

(C) М. О. Кириченко, 2019 
24. Steven Pinker (2019). Enlightenment now. Arguments in favor of reason, science and progress / lane. with the English. Elena Lyubenka. PS: Our format. 560.

25. Starzhinsky, V. P. (2016). Towards an Innovation Society. Minsk: RIVSh, 446.

26. Sosnin, O. V., Voronkova V. H., Nikitenko, V. O., Maksymeniuk, M. Yu. (2017). Informaitsino-komunikatyvnyi menedzhment: zarubizhnyi i vitchyznianyi menedzhment. Kyiv: KPI im. Ihoria Sikorskoho, Vyd-vo «Politekhnika», 316.

27.Tegmark, Max (2017). Life 3.0. Being Human in the age of artificial Intelligence. New York: Alfred A.Knopf. 432.

КИРИЧЕНКО МИКОЛА ОЛЕКСІЙОВИЧ - доктор філософії, професор кафедри філософії і освіти дорослих, член-кореспондент Академії наук вищої освіти України, ректор ДЗВО «Університет менеджменту освіти» Національної академії педагогічних наук України (Київ, Україна)

E-mail: kmumo@i.ua

ORCID 0000-0003-1756-9140

\section{ВПЛИВ ЦИФРОВИХ ТЕХНОЛОГІЙ НА РОЗВИТОК ЛЮДСЬКОГО І СОЦІАЛЬНОГО КАПІТАЛУ В УМОВАХ ДІДЖИТАЛІЗОВАНОГО СУСПІЛЬСТВА}

Анотація. Тема, що обрана для розгляду, є надзвичайно актуальною, має велике теоретичне і практичне значення, тому що цифровий світ невпинно розвивається i впливає на технологічні можливості сучасної людини, яка повинна постійно збільшувати свої ресурсні можливості і капітал. Цифрові технології невпинно змінюють сучасний ринок, вони створили умови для появи паралельних валют, стерли можливості між роботою та вільним часом, вплинули на формування цифрової людини і цифрової свідомості, розвиток цифрових технологій позначиться і в майбутньому на цифровому розвитку економіки майбутнього. На цифровий розвиток постійно впливають технічні та технологічні зміни, які відбиваються на людському i соціальному капіталі. Рівень людського і соціального капіталу сучасної людини повинен включати обізнаність та високу технологічну підготовку, щоб діяти у цифровому світі, функціонувати у добре функціонуючих комунікаційних межах по всій країні. Аналіз останніх досліджень $і$ публікацій - ми спираємося на останні роботи у світі цифрових технологій, а саме Ендрю Макафі, Еріка Бріньолфссона «Машина, платформа, натовп. Як приборкати наше цифрове майбутнє»; Девіда Роуза «Дивовижні технології. Дизайн та інтернет речей»; Пол Мейсона «Посткапіталізм»; Джо Стадвелла «Чому Азії вдалося. Успіхи і невдачі найдинамічнішого регіону світу»; Ручіра Шарма «Передові країни. В очікуванні нового «економічного дива»;

Ешлі Венса «Ілон Маск. Tesla, Spacex і шлях у фантастичне майбутнє»; Ліендера Кені «Тім Кук. СЕО, що вивів Apple на новий рівень» та ряду робіт вітчизняних авторів - Д.Свириденко, О.Кивлюк, С.Куцепал, О.Сосніна, О. Пунченка, в яких досліджуються дотичні теми до цієї проблеми. Методи - сукупності знань про системи складності, так як цифрова ера вимагає системного мислення у нових категоріях, щоб краще зрозуміти й вдосконалювати технологічні процеси. Системна динаміка може потужніше впливати на розвиток технологічного світу та ідеологію і світогляд сучасної людини, ніж параметри окремих іiі компонентів. Виділення невирімених раніше частин загальної проблеми, котрим присв'ячується означена стаття. В основі дослідження - вПлив цифрових технологій на ровиток людського і соціального капіталу, тому що технологічна галузь - найдинамічніша у сучасному світі, вона здатна суттєво змінити

Вплив цифрових технологій на розвиток людського і соціального капіталу в умовах діджиталізованого суспільства 
наше життя у недалекому майбутньому. Мета статті - концептуалізація впливу цифрових технологій на розвиток людського і соціального капіталу. Результати дослідження. Доведено, що поширення цифрових технологій виступає як мегатренд цифрової економіки та управління. Виявлено мегатренди цифрової економіки та цифрового менеджменту, які впливають на розвиток людського і соціального капіталу коштовний друк (бренд 2013); невидимі технології; «розумні міста»; робототехніка; штучний інтелект; інтернет речей; Big data (великі дані). Показано вплив цифрових технологій на зростання і поширення економічної активності та розвиток людського і соціального капіталу. Розкрито умови створення нових знань і технологій як чинник розвитку людського і соціального капіталу. Досліджено місце і роль Інтернету як платформи для розвитку людського і соціального капіталу. Обгрунтовано, що вплив цифрових технологій на розвиток людського i соціального капіталу виступає каталізатором збільшення інтелектуально-цифрових можливостей людини, здатної жити у цифрову еру.

Ключові слова: цифрові технології, людський і соціальний капітал, штучний інтелект, робототехніка, діджиталізоване суспільство

Кириченко, Николай Алексеевич - доктор философии, профессор кафедры философии и образования взрослых, член-корреспондент Академии наук высшего образования Украины, ректор «Университета менеджмента образования» Национальной академии педагогических наук Украины (Киев, Украина)

E-mail: kmumo@i.ua

ORCID 0000-0003-1756-9140

\section{ВЛИЯНИЕ ЦИФРОВЫХ ТЕХНОЛОГИЙ НА РАЗВИТИЕ ЧЕЛОВЕЧЕСКОГО И СОЦИАЛЬНОГО КАПИТАЛА В УСЛОВИЯХ ДИДЖИТАЛИЗИРОВАННОГО ОБЩЕСТВА}

Аннотация. Тема, которая избрана для рассмотрения, есть чрезвычайно акутальной, потому что имеет большое теоретическое и практическое значение, так как цифровой мир неустанно развивается и влияет на технологические возможности современного человека, которые неустанно увеличивают его ресурсные возможности и капитал. Цифровые технологи неустанно изменяют современный рынок, они создали условия для\ появления\ параллельных ваолют, стерли возможности между работой и свободгнмы временем, повиляли на формирование цифрового человека и цифрового сознания, развитие цифровых технологий повлдияеит в будущем на цифровое развитие эконмики будущего. На цифровое развитие постоянно влияют технические и технологические изменения, которые ображаются на человеческом и социальном капитале. Уровень человеческого и социального капитала человека должен включать эрудированность и высокую технологическую подготовку, чтобы действовать в цифровом мире, действовать в хорошо функционируюших коммуникационных сетях по всей стране. Анализ последних исследований и публикаций - мы опираемся на последние работы в мире цифровых технологий, а именно Эндрю Макафи, Эрика Бринелфссона «Машина, платформа, толпа. Як укротить наше цифровое будущее»; Девида Роуза «Дивные технологии. Дизайн и интернет вещей»; Пол Мейсона «Посткапитализм»; Джо Стадвелла «Почему Азии получилось. Успехи и нудачи самого динамического региона мира»; Ручира Шарма «Передовые страны. В ожидании нового «экономического чуда»; Эшли Венса «Илон Маск. Tesla, Spacex и путь в фантастическое будущее»; Лиендера Кени «Тим Кук. СЕО, который вывел Apple на новый уровень» и ряда работ отечественных учених - Д.Свириденко, О.Кивлюк, С.Куцепал, А.Соснина, О.Пунченка, в которых исследуются аналогиченные темы этой

(C) М. О. Кириченко, 2019 
проблемы. Методы - совокупность знаний о системах сложности, так как цифровая эра требует системного мышления в новых категориях, чтобы лучше понимать и усовершенствовать технологические процессы. Системная динамика может мощнее влиять на развитие технологического мира, идеологию и мировоззрение современного человека, нежели параметры отдельных ее компонентов. Выделение нерешеннных ранее частей общей проблемы, которым посвящается данная статья. В основе исследования - влияние цифровых технологий на развитие человеческого и социального капитала, потому что технологическая отрасль - самая динамическая в современном мире, которая способна существенно изменить нашу жизнь в недалеком будущем. Цель статьи - концептуализация влияния цифровых технологий на развитие человеческого и социального капитала. Результаты исследования. Доказхапно, что расмпространение цифрових технологий выступает как мегатренд цифровой экономики и управления. Выявлены мегтренды цифровой экономики и цирфового менеджмент, котьорые влияют на развитие человеческолго и социального капитала - дорогоценная печать (бренд 2013); невидимые технологии; «умные города»; робототехника; искусственный интеллект, интернет вещей; Big data (большие данные). Описано влияние цифровых технологий на увеличение и распространение экономической активности и развитие человеческого и социального капитала. Раскрыты условия создания новых знаний и технологий как фактор

развития человеческого и социального капитала. Изучено место и роль Интернета как платформы для развития человеческого и социального капитада. Обосновано, что влияние цифровых технологий на развитие человеческого и социального капитала выступает катализатором увеличения интеллектуально-цифровых возможностей человека, способного жить в цифровую эру.

Ключевые слова: цифровые технологии, человеческий и социальный капитал, искусственный интеллект, робототехника, диджитализированное общество.

Received date 12.09.2019

Accepted date 15.10.2019

Published date 15.11.2019

Вплив цифрових технологій на розвиток людського і соціального капіталу в умовах діджиталізованого суспільства 